\title{
Improvement classification of law terms through content-based learning
}

\section{Shahribonu SIROJIDDINOVA ${ }^{1}$ Ganisher RAHIMOV²}

Samarkand state institute of foreign languages

Denau Institute of Entrepreneurship and Pedagogy

\begin{tabular}{l} 
ARTICLE INFO \\
\hline Article history: \\
Received March 2021 \\
Received in revised \\
20 March 2021 \\
Accepted 15 April \\
Available online \\
20 May 2021 \\
\\
\hline Keywords: \\
law, \\
international law, \\
legal terms, \\
lexical units, \\
translation, \\
terminology, \\
legalization, \\
contract, \\
documents, \\
dictionary, \\
proficiency, \\
comparison.
\end{tabular}

ABSTRACT

This research work is devoted to the features of the classification of legal terminology through content based learning. Including these legal services are necessary in professional activities. A high-quality written classifying terms through content based will be useful, for example, both for the owner of a judicial organizations who has concluded a lucrative contract abroad and for an ordinary foreman who wants to read a competent classification of instructions for legal documents.

2181-1415/@ 2021 in Science LLC.

This is an open access article under the Attribution 4.0 International (CC BY 4.0) license (https://creativecommons.org/licenses/by/4.0/deed.ru)

\section{Tarkibga asoslangan ta'lim orqali huquqiy atamalar tasnifini takomillashtirish}

\author{
Kalit so'zlar: \\ huquq, \\ xalqaro huquq, \\ yuridik atamalar, \\ leksik birliklar, \\ tarjima, \\ terminologiya, \\ legallashtirish,
}

\begin{abstract}
ANNOTATSIYA
Ushbu ilmiy ish huquqiy terminologiyani maxsus qismlarga ajratgan holda o'rganish xususiyatlariga bag'ishlangan. Ushbu yuridik xizmatlar, shu jumladan kasbiy faoliyat uchun zarurdir. Yuridik mavzulardagi yuqori sifatli turlanish, masalan, chet elda foydali shartnoma tuzgan sud tashkilotining egasi uchun ham, yuridik hujjatlar uchun ko'rsatmalarning malakali tarjimasini o'qishni istagan oddiy mutaxassis uchun ham foydali bo'ladi.
\end{abstract}

\footnotetext{
${ }^{1}$ Lecturer of Samarkand state institute of foreign languages, Samarkand, Uzbekistan.

${ }^{2}$ D.Sc., Prof, Rector of the Denau Institute of Entrepreneurship and Pedagogy, Denau, Uzbekistan.
} 
shartnoma,

hujjatlar,

lug'at,

bilim,

taqqoslash.

\section{Улучшение классификации юридических посредством обучения на основе содержания}

терминов

Ключевые слова:
право,
международное право,
юридические термины,
лексические единицы,
перевод,
терминология,
легализация,
договор,
документы,
словарь,
знание, сравнение.

\begin{abstract}
АННОТАЦИЯ
Данная исследовательская работа посвящена особенностям классификации юридической терминологии. В том числе эти юридические услуги необходимы в профессиональной деятельности. Качественная классификация по юридической тематике будет полезна, например, как владельцу судебной организации, заключившему выгодный контракт за рубежом, так и рядовому мастеру, желающему прочитать грамотный перевод инструкций к юридическим документам.
\end{abstract}

The classification of scientific and technical terms. The question of classifying scientific and technical terms has always been and remains relevant today. The constant replenishment of dictionaries with new terms is the main proof of this.

As a rule, all terms are divided into: [1. P. 8].

1. Simple (consisting of one word). For example, baffle - visor, flap.

2. Complex (of two or more words and usually written in a fused or hyphen). For example, electromagnetic is electromagnetic.

3. Complex terms are phrases. For example, block-schematic diagram (BSD), translated into Uzbek as a block scheme.

B.N. Klimzo gives the following classification of terms:

1. Terms - tracing by name it is easy to guess that the way to translate this group of terms is calcification, in other words, verbatim translation. According to Klimzo, there are often tracings in scientific and technical texts. For example, the term elastic solution can be translated as "elastic decision" (rather than "elasticity decision"). But it is worth noting that if the frequency of using the same term in the text is high, it is best to apply the method of calcification in the first case of using the term, but the second, more detailed option should be specified in brackets.

2. "Tricky" two-component terms the author calls two-component terms that contain two words. A distinctive feature is that when translated they change places, i.e. the definition becomes defined and vice versa. Boris Klimzo proves this by citing a number of examples, such as the schedule estimate, a two-part term that we will translate into Uzbek as "indicative graph" rather than "planned assessment"; example problems are "examples of problem solving" rather than "example tasks" and a number of others.

3. Multi-component terms by name it is easy to guess that multi-component terms are called, consisting of several words, which do not have grammatical connections. Moreover, context is an important role in translating a multi-component term. 
Translator resources Variety of dictionaries, sources that can be used by a specialist for translation of terminology and scientific and technical texts in general is extremely high. Every day the volume of translations is increasing, and this suggests that translation requirements are becoming more stringent, and translators, in turn, are looking for the most convenient, quality resources that could optimize the translation process. To date, translators have almost all the means to simplify the translation process.

For example

1. Internet;

2. Specialized terminological dictionaries and glossaries;

3. Automatic and machine translation programs;

4. Electronic libraries;

5. Bilingual Dictionaries

According to Shevchuk V.N. [27. P. 9], there are two views on the effectiveness of the use of electronic resources in the translation process. that there are more opportunities thanks to the rapid access to the Internet, where it is possible to find, translate, check everything that is required. In his work "Designing Translational Dictionaries of Special Vocabulary" he states that there is no generally accepted definition for the concept of "dictionary" to date [16. P. 15-16].

Turning directly to the types of dictionaries that exist today, we should speak, first of all, about their relevance:

1. Paper dictionaries. As a rule, an interpreter can only use this type of resource if there is no electronic dictionary nearby. Over time, the latter increasingly displaces the paper version of the assistant. Finding the right term takes a huge amount of time, and one of the main drawbacks of such dictionaries is the weak saturation of terms.

One of the most common features of scientific text is the use of verbs, different forms of which are also found in this body of text:

1. The verbs of the perfect kind, used in stable turns (consider as a photon crystal...; in conclusion, it should be noted that the increase in the mobility of the carriers in the crystal...; note the relative nature of the concept of superpositional state..

2. Return verbs in passive meaning, the use of which is due to the fact that, describing a particular process, structure, etc., attention is focused on themselves, and not on the manufacturer of action (n.r. the dependence of the efficiency of pumping from the angle of the crystal...) and etc.

Our practical work begins with a program called "Lana-key" and how the program works. To begin with, terms can be represented by different parts of speech, and, as we mentioned in the previous section, one of the main signs that the scientific text before us is the use of verbs in different forms. But in our research work the most interesting is the translation and analysis of name phrases, as they make up the main and most frequency layer of vocabulary, which is much wider than the concept of "terminology". Therefore, with the help of the Lana key text automatically processing program, all the name phrases were selected and sorted by frequency. As a final result, Lana-key presents a list of 1-, 2-, 3- and 4-word name phrases, with certain characteristics such as length, place in the text, frequency of the term itself, and the likelihood of entering longer multi-component phrases, which must necessarily be checked in the text.

One of the main advantages of the Lana key program is the selection of multicomponent name phrases in the text, or 4-grams, which need to be given special attention, as they are more difficult to translate and understand. This once again confirms the relevance of our study, because scientific and technical terminology is becoming more 
diverse, and every day there are more and more complex, multi-component terms, which, as a rule, because of their novelty, are still absent in paper dictionaries. And the task of the translator in this problem is to regularly monitor the updates and changes that occur in the field of knowledge in which he is a specialist, as well as to know how to properly translate the name phrases. And here it is appropriate to pay attention again to the fact that optoinformatics - a completely new, little-studied science, research in which just lead to the emergence of such complex terminology. And the perspective to solve this problem opens the program Lana key, which may well be a good help in the creation of electronic dictionaries containing complex, multi-component vocabulary, relevant to a particular area of knowledge.

The program automatically saves the list of all n-gr and the next stage in our work will be the compilation of Uzbek glossary of multi-component terms. This means that we need to clear the list, leave only correct terms, that is, exclude those 4-gr in which the components are not related.

A large number of multi-component terms were removed from the list due to the fact that: 1. 4-gr ended in communion. For example, the profile ratio of decay tunneling (2), the interval of angles field leaking (1), fading of the main fashion following (1), the specified critical angle of the attached (1), the boundary part of the power falling (1), the i1 integral intensity of the increasing (1). These examples show us that such combinations of words cannot be referred to as multi-component terms, as they either do not find a continuation in the text or, to other things, are incorrect. One component of 4-gr is the verb. For example, q-esy fashion designate (1), limit the maximum sensitivity of photoreceptors (1), normalize scalar wave solutions (1), easily give a simple shape (1), flesh out the law of density change (1). Obviously, we're dealing with name phrases that just can't be used with verbs. It is also important to note that when sorting and cleaning a list of multicomponent items to exclude incorrect items, the translator's task is greatly facilitated by the introduction of verbs in the search engine in order to remove them from the list immediately.

Translational hypothesis. Specifics and problems of translation of scientific and technical multi-component terms. As mentioned above, 4 component name phrases are the most difficult to translate into English.

1. Since we consider the specifics of translation of multi-component terminology, and as mentioned above, it is almost impossible to find such a term in the paper dictionary in its full version. In this case, the translator must refer to the terminological dictionaries in order to find a translation of each n-gram component separately. For example, consider a four-part term called full power of the beams being sent. Divide it into two components: full power and directed beams. One of the most effective methods to test the hypothesis a search engine on the Internet. It is such because, when requesting the term in the search bar, we see the frequency of use of terms in texts of different areas of knowledge and can choose the one that is used in ours.

By translating the first component in the terminology dictionary, we get a full capacity translation. The translation of the second component in our hypothesis will sound like directed beams. By combining the two elements, we receive a translation: the full capacity of the directed beams. In order to make sure that the translated group is correct, let's enter the received translation of the term into a search bar. Sometimes, search engines can display a complete translation of one or even two components, but in this case, you need to be extremely careful in the texts of what nature the term meets, or part of it. In our 
case, we see that the version of this formulation of translation of the term is not found in the search engines Google and Yandex.

2. Where the terminological dictionary and search engines fail to do the job, Transdict, a bilingual lexicographical knowledge base, can be a good helper in translating scientific and technical terminology. The dictionary includes only a limited set of values in each zone: not everything in the language, but just what you might need to automatically process highly specialized texts and make this processing less complex. The main advantage is that Transdict includes the translation of name phrases pertaining to the area of knowledge we are exploring. Another advantage of the programme is the introduction and preservation of multi-component terms, which are then tested by experts in the field.

Thus, by compiling a translational hypothesis, which in most cases can be trusted, but always to question and verify the correctness of a term, as well as the use of specialized dictionaries of automatic translation, which relate to narrow areas of knowledge - makes the task of translating a complex, multi-component term much easier.

\section{Conclusion}

Due to the rapid development of technology, the need for a qualitative classification of scientific and technical terminology is becoming more and more tangible. Companies need specialist translators in various fields of expertise. The first chapter examines the basic concepts related to the translation of scientific and technical terminology, the peculiarities of scientific texts and the difficulties that can arise in translation.

\section{REFERENCES:}

1. ABBYY Lingvo 11 / Six languages. Electronic dictionary. Release 11.0.0.291. ABBYY Software, 2005.

2. Alicia Edwards in The Practice of Court Interpreting. Philadelphia, PA: John Benjamins Publishing, 1995

3. Krylov A.I. Language units and context. - L.: 1973.

4. Shevchuk V.N. Electronic resources of the translator / V.N. Shevchuk. - M.: Zebra E, 2013. - P. 130.

5. Smekaev V.P. Modern technical translation [Text]: textbook: English / V.P. Smekaev. - M.: R. Valent, 2014. - P. 359.

6. The Costitution of the United Kingdom. Institute for Public Policy Research, Southampton Street, London, 1991.

7. A dictionary of law. Fourth Edition. Ed. By Elizabeth A. Martin. Oxford, New York. Oxford University press. 1997. - P. 515.

8. A Dictionary of Law. Sixth edition. Edited by Elizabeth A. Martin, Jonathan Law. Oxford University Press, 2006.

9. Collins Dictionary [Electronic resource]. - Access mode: http://www. collinsdictionary.com /dictionary/english. - Access date: 4/11/2014.

10. Longman Dictionary of Contemporary English. Web Dictionary. [Electronic media]. - Pearson Education Limited, 2000.

11. Carolina Association of Translators and Interpreters. Website of the Association of Interpreters and Translators of North and South Carolina (USA). Access mode: http://www.catiweb.org.

12. Consortium program for Court Interpreters. Access mode:www.ncsconline.org/ 
D_Research/CourtInterp.html.

13. [Electronic resource]. - Access mode: slovari.yandex/dict/krugosvet/article/0/ 09/1007732.htm.

14. Handbook on the registration of regulations. E-resource. Access mode: http://www.garant.ru.Access date: 03.11.2014.

15. Maryland Court Interpreting Programme. Access mode:http://www.courts. state.md.us/interpreter/index.html; http://www.mdcourts.gov/interpreter/index.html.

16. National Association of Judiciary Interpreters and Translators (NAJIT) Access Mode:www.najit.org / NAJIT Position Paper, NAJIT Code of Ethics and Professional Responsibilities. Access mode:www.najit.org/ethics.html. NAJIT Position Paper Direct Speech in Legal Settings Interpreting in the Courtroom, Access Mode: http://najit.org/documents/ Team_Interpreting.pdf.

17. Professional Ethics and the Role of the Court Interpreter, 3rd Edition, 2001, Judicial Council of California p. 25. Access mode:http://www.courtinfo.ca.gov/ programs/courtinterpreters/ documents/ethicsman.pdf.

18. The EU's Multilingual Term Base [Electronic resource]. - Access mode: http://iate.europa.eu/switchLang.do?success=mainPage\&lang $=$ en. - Date of access:11/7/2014.

19. V.M. Leichik The culture of the term [Electronic resource]. - Access mode: www.library.krasu / ft / ft /_articles / 0113944.pdf. 